Article

\title{
Integrated SNG Production in a Typical Nordic Sawmill
}

\author{
Sennai Mesfun ${ }^{1, *}$, Jan-Olof Anderson ${ }^{2}$, Kentaro Umeki ${ }^{1}$ and Andrea Toffolo ${ }^{1}$ \\ 1 Energy Engineering, Luleå University of Technology, SE-97187 Luleå, Sweden; kentaro.umeki@ltu.se (K.U.); \\ andrea.toffolo@1tu.se (A.T.) \\ 2 Process Energy Engineering, Solvina, SE-42130 Västra Frölunda, Sweden; jan.olof.anderson@solvina.se \\ * Correspondence: sennai.mesfun@ltu.se; Tel.: +46-920-49-2436
}

Academic Editor: Jean-Pierre Bédécarrats

Received: 4 February 2016; Accepted: 25 April 2016; Published: 30 April 2016

\begin{abstract}
Advanced biomass-based motor fuels and chemicals are becoming increasingly important to replace fossil energy sources within the coming decades. It is likely that the new biorefineries will evolve mainly from existing forest industry sites, as they already have the required biomass handling infrastructure in place. The main objective of this work is to assess the potential for increasing the profit margin from sawmill byproducts by integrating innovative downstream processes. The focus is on the techno-economic evaluation of an integrated site for biomass-based synthetic natural gas (bio-SNG) production. The option of using the syngas in a biomass-integrated gasification combined cycle (b-IGCC) for the production of electricity (instead of SNG) is also considered for comparison. The process flowsheets that are used to analyze the energy and material balances are modelled in MATLAB and Simulink. A mathematical process integration model of a typical Nordic sawmill is used to analyze the effects on the energy flows in the overall site, as well as to evaluate the site economics. Different plant sizes have been considered in order to assess the economy-of-scale effect. The technical data required as input are collected from the literature and, in some cases, from experiments. The investment cost is evaluated on the basis of conducted studies, third party supplier budget quotations and in-house database information. This paper presents complete material and energy balances of the considered processes and the resulting process economics. Results show that in order for the integrated SNG production to be favored, depending on the sawmill size, a biofuel subsidy in the order of $28-52 € / M W h$ SNG is required.
\end{abstract}

Keywords: sawmill; bio-SNG; b-IGCC; process integration; HEATSEP method; techno-economic evaluation

\section{Introduction}

Sweden has a large sawmill industry with an annual production capacity of about 16.1 million cubic meters of sawn wood in 2013 [1]. The corresponding amount of biomass by-products, in the form of woodchips, bark and sawdust, is about the same in terms of dry mass [2]. Biomass utilization has been gaining interest as a means to achieve the targets related to the reduction of greenhouse gas emissions and to the increase of the share of renewables in the energy mix. Woody-biomass is one of the important renewable energy sources (RES) that are globally expected to play a major role in mitigating the dependence of modern society on fossil-based resources for household, industry and transportation energy use. There are, however, several problems associated with the different forms of RES, such as the uneven distribution of the resources around the globe, the insufficient availability of the resources (as long as the objective is to fulfill a significant share of the global primary energy demand according to the best conversion technology known today) and the difficulties with storing them (in the case of intermittent resources, such as solar and wind) [3]. 
It is essential that biomass can be converted to energy products that correspond to the standards of existing fossil-based energy carriers, such as electricity, chemicals, gas and transportation fuels. The merits in doing so include the alleviation of the burden on the environment from greenhouse gas emissions (bioenergy is considered as $\mathrm{CO}_{2}$ neutral) and utilization of the existing infrastructure (trade and supply network of the long-established products) and applications [3-8].

A typical case is the production of biomass-based substitute/synthetic natural gas (bio-SNG) from lignocellulosic biomass. The bio-SNG process has been gaining interest as a promising downstream technology via thermal gasification of biomass. Several plausible alternative processes are reported in the literature; see, e.g., [3,6,9-13]. The production of SNG from biomass is generally considered to be made of three main process stages: gasification of the lignocellulosic biomass into raw syngas (mainly composed of $\mathrm{H}_{2}, \mathrm{CO}, \mathrm{CO}_{2}$ and $\mathrm{CH}_{4}$ on a dry basis), methanation (catalytic conversion of the syngas into crude SNG) and upgrading of the crude $\mathrm{SNG}$ to the gas pipeline specifications (which implies $\mathrm{CO}_{2}$ and $\mathrm{H}_{2} \mathrm{O}$ removal). Others studies (see, e.g., [14-17]) also focus on the production of SNG from various renewable energy resources, such as wind and solar via electrolysis of water to produce hydrogen, which afterwards is used in hydrogenation of $\mathrm{CO}_{2}$ to produce SNG.

In this work, the potential for upgrading the by-products of a typical Nordic sawmill into bio-SNG is investigated from a techno-economic point of view. The main technologies considered for the bio-SNG production are a pressurized bubbling fluidized bed reactor (see, e.g., [18]) for the thermal gasification of biomass, the Imperial Chemical Industry (ICI) process [6] for methanation and amine-based $\mathrm{CO}_{2}$ separation (see, e.g., [19]) for bio-SNG upgrade. In addition, the investigation includes the option of utilizing the product gas in a biomass-integrated gasification combined cycle (b-IGCC) in order to produce heat and electricity. In turn, the b-IGCC configuration has two alternative options: supplying low temperature thermal energy to a district heat $(\mathrm{DH})$ system or condensing the steam below atmospheric pressure in order to maximize the electrical output.

The paper is organized as follows. Section 2 presents a description of the considered processes. The methodologies used for process integration, as well as for energetic and economic evaluations are presented in Section 3. Section 4 summarizes the results and includes a discussion about the most significant findings.

\section{Process Description}

\subsection{Sawmill}

The sawmill is a process industry that converts timber (the round beam section of a tree, without branches and tops) into lumber (wooden board used in wood industries and construction). In so doing, sawmills produce a large quantity of by-products (in the form of woodchips, sawdust and bark) that can be utilized by innovative bioenergy technologies.

The model of a typical Nordic sawmill is taken from [2]. Accordingly, about $47 \%$ of the timber input is converted into lumber (the main product) on a dry mass basis. The remaining $53 \%$ is a by-product with respect to the sawmill process. This by-product, the biomass fuel mix (BFM), is composed of woodchips (about $26 \%$ of the timber input on a dry mass basis), bark (19\%) and sawdust $(8 \%)$. If the sawmill is not integrated with other processes/plants that can supply heat, an amount of BFM corresponding to $10.3 \%$ of the timber input on a dry mass basis has to be consumed internally in a dedicated furnace mainly to satisfy the lumber drying process [2]. In fact, timber is initially supplied at $55 \%-60 \%$ moisture content, while lumber has a final moisture content of $18 \%$. Therefore, the lumber drying process is quite energy intensive and is carried out by circulating heated outdoor air through packages of lumber that are placed in dedicated rooms called drying kilns. The outdoor air, initially at $2{ }^{\circ} \mathrm{C}$, is heated to about $75^{\circ} \mathrm{C}$ and is continuously supplied to the drying kilns to replace the humidified air inside the kilns. 


\subsection{SNG Process}

The SNG process consists of a biomass dryer, an air separation unit (ASU), a bubbling fluidized bed gasifier, gas cleaning units, SNG synthesis units and a $\mathrm{CO}_{2}$ separation unit; see Figure 1. Oxygen and steam gasification is chosen because it already produces a small amount of methane, and a detailed description of the process model is reported in [20]. The biomass fuel, initially at $55 \%-60 \%$ moisture content, is dried to a final moisture content of about $10 \%$ using hot air as the drying medium in a belt conveyor dryer. The drying air and the dried biomass exit the dryer at the same final temperature of about $110{ }^{\circ} \mathrm{C}$. In the gasifier, a mixture of steam and $\mathrm{O}_{2}$ is used as a gasifying agent. The flow rate of steam is kept constant at the steam to biomass ratio of $0.5 \mathrm{~kg} / \mathrm{kg}$-biomass, while the flow rate of $\mathrm{O}_{2}$ is adjusted to keep the gasification temperature at $850^{\circ} \mathrm{C}$. The ICI process [6] is chosen for the SNG synthesis units to achieve a high conversion to methane. The ICI process consists of three fixed bed catalytic exothermic reactors in series (adiabatic equilibrium reactors), and methanation is assumed to proceed according to reactions R1 and R2.

$$
\begin{array}{ll}
\mathrm{CO}_{2}+4 \mathrm{H}_{2} \leftrightarrow \mathrm{CH}_{4}+2 \mathrm{H}_{2} \mathrm{O} & \Delta \mathrm{H}_{298 \mathrm{~K}}^{\mathrm{O}}=-165 \mathrm{~kJ} / \mathrm{mol} \\
\mathrm{CO}+3 \mathrm{H}_{2} \leftrightarrow \mathrm{CH}_{4}+\mathrm{H}_{2} \mathrm{O} & \Delta \mathrm{H}_{298 \mathrm{~K}}^{\mathrm{O}}=-206 \mathrm{~kJ} / \mathrm{mol}
\end{array}
$$

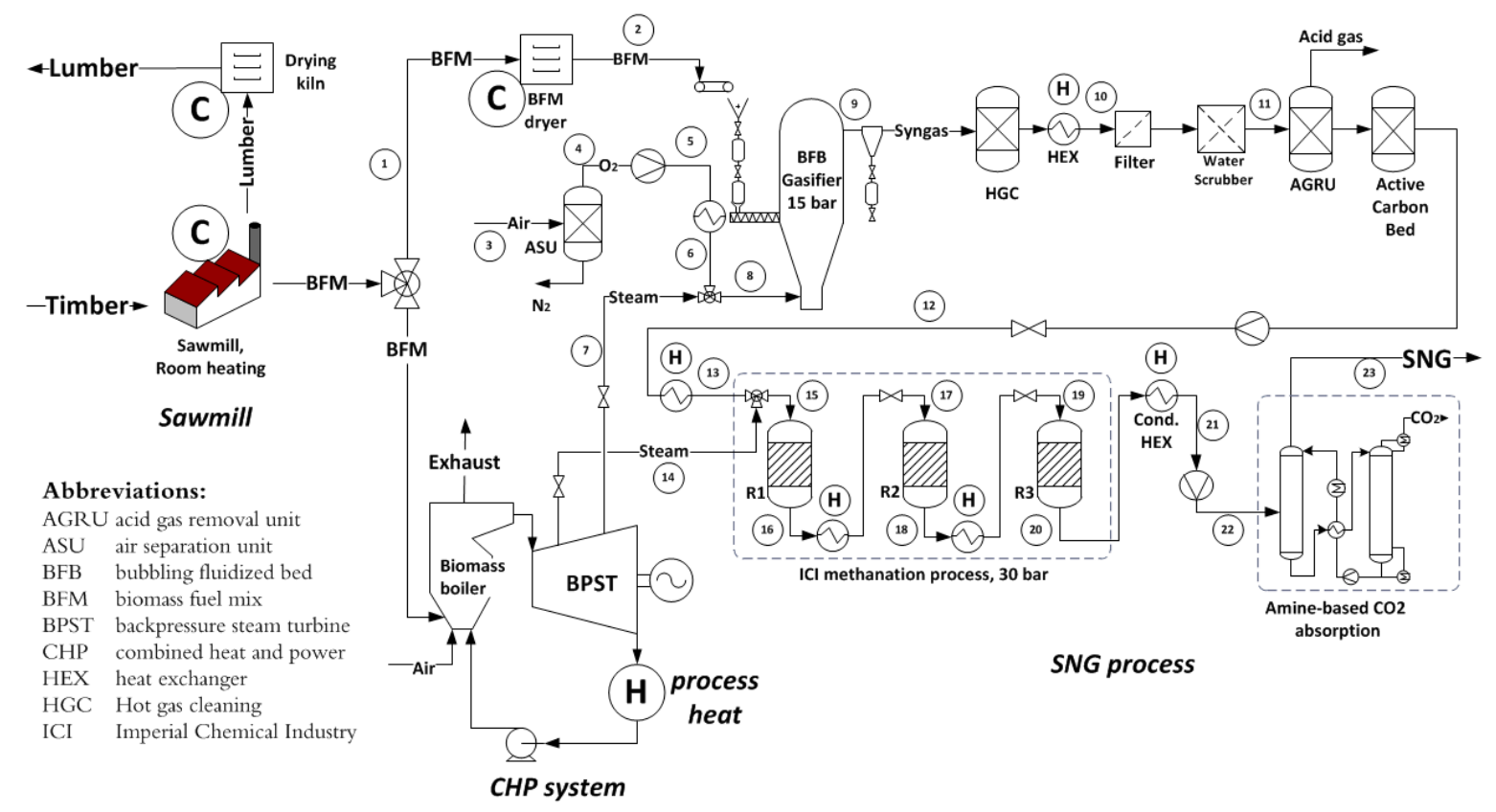

Figure 1. Bio-SNG production process flowsheet (circles with $\mathrm{H}$ and $\mathrm{C}$ represent hot and cold thermal streams, respectively).

The reactors are fitted with intercooling heat exchangers in between in order to compensate the heat from exothermic reactions. In this work, amine-based $\mathrm{CO}_{2}$ separation is assumed for gas upgrading, as it is a proven technology that is commercially available and used in many industries. The overall SNG process includes also a boiler in which part of the biomass is burnt in order to supply the heat demand of the SNG process, as well as of the sawmill.

\section{3. $b$-IGCC Process}

The considered b-IGCC process assumes similar pretreatment, gasification and gas cleaning technologies as in the SNG process except that air is used as a gasifying medium instead of a mixture of oxygen and steam. In this case, the cleaned product gas is first utilized in a stationary gas turbine 
engine to generate electricity, then the exhaust gas from the gas turbine is sent to an heat recovery steam generator (HRSG) to generate high pressure steam that is expanded in a steam turbine (backpressure or condensing, depending on the bottom cycle configuration of the b-IGCC) to produce additional electricity. In the alternative with $\mathrm{DH}$, a backpressure steam turbine is used that expands the steam down to 1.9 bar (a pressure level that is suitable to satisfy the sawmill heat demand). The heat derived from steam condensation is first used to satisfy the sawmill thermal deficit, and then, the rest is supplied to the $\mathrm{DH}$ system. In the alternative without $\mathrm{DH}$, the steam that is not used to satisfy the thermal demand of the sawmill is expanded down to 0.05 bar in a condensing turbine to generate additional power instead of supplying heat to a DH system.

\section{Methodology}

Process integration techniques are used to evaluate the profitability of integrating a typical Nordic sawmill with the production of biomass gasification-based bio-SNG and/or power under different process configurations and sawmill sizes. The mass and energy balances of the processes are obtained from plant models developed in MATLAB and Simulink. In all of the cases, the amount of available BFM is limited to the amount of by-products from the considered sawmill size. The mass and energy balances of each process configuration are further constrained by the fulfillment of the heat demand of the sawmill.

Under these conditions, the following three process configurations have been considered:

- Integration of the bio-SNG production process described in Section 2;

- Integration of a b-IGCC system that produces electricity and heat for a DH system;

- Integration of a b-IGCC system with the sole purpose of producing electricity.

\subsection{Process Integration}

The processes considered in this work involve hot thermal streams at different temperature levels. This surplus of thermal energy can be used to supply the heat demand of the sawmill, the heat and steam demand of the bio-SNG process and, potentially, to cogenerate electricity in a steam Rankine cycle. Accordingly, the HEATSEP method [21] is applied to the flowsheets of the processes (including the sawmill and the steam Rankine cycle) in order to assess the synergy among them. The HEATSEP method allows one to focus on the basic process units of a system configuration by replacing the potential heat transfer devices with the so-called "thermal cuts". The thermal streams (hot and cold) across the cuts are then grouped into a "black box" where heat exchange interactions are assumed to take place without predefined stream matches. The temperatures at the boundaries of the thermal cuts and the mass flow rates of the streams are included among the decision variables during the search for the optimal configuration and design parameters of the different processes (see, e.g., [22], in which the objective function is to maximize the net power output of a steam Rankine cycle that is shared among different processes in a pulp and paper mill). The feasibility of the heat transfer inside the "black box" is a constraint of the optimization problem and is verified according to the problem table algorithm [23].

In this work, the temperatures (and several of the mass flow rates) across the thermal cuts in the bio-SNG process, in the b-IGCC process and in the sawmill are fixed, so they are not considered among the decision variables of the optimization problem. The fixed values for these quantities are subject to change according to the capacity of the sawmill, mainly because the efficiencies of the components improve when the size is increased. As a result, the corresponding hot and cold thermal loads are not exactly proportional to the capacity of the sawmill, although the configurations of the system remain the same as the sizes are varied. The design parameters of the steam Rankine cycle are therefore those that have to be optimally tuned in order to generate the maximum power from the exploitation of the heat pockets of the grand composite curve of the other processes in the integrated industrial site. These optimal parameters will then depend on the system configuration and on the size of the sawmill. 
The bio-SNG process requires steam at 15 and 30 bars during the gasification and methanation steps, respectively. In the process configuration with SNG production only, the surplus heat from the high temperature streams of the bio-SNG process is not enough to generate the amount of steam required, so a boiler that burns a fraction of the available BFM is included in the flowsheet in order to satisfy the deficit. This imposes an additional constraint on the amount of BFM retained for bio-SNG production. The steam cycle is designed to generate steam at pressures that are high enough to meet the bio-SNG process steam demand while cogenerating electricity in a steam turbine. The heat demand of the sawmill is also satisfied using condensing steam at 1.9 bar. It should also be noted that an amount of feed water equal to the amount of steam consumed by the gasification and methanation processes must be continuously supplied to the steam Rankine cycle. As a result, the decision variables are the maximum cycle pressure and temperature of the steam Rankine cycle, the mass flow rate of steam that remains in the steam cycle and the split fraction of the BFM that goes to the boiler (this last one, however, is heavily affected by constraints on the grand composite curve in the middle and high temperature ranges).

On the contrary, the b-IGCC process configurations involve high temperature hot streams resulting in a surplus heat that is larger than the demands of the b-IGCC process and of the sawmill. In this case, the steam Rankine cycle is mainly designed to exploit the excess heat for cogenerating electricity and to add flexibility for the heat transfer interactions among the different processes. In fact, the design of the steam Rankine cycle helps with minimizing the exergy destruction that would have occurred if the high temperature hot streams were used to supply directly low temperature heat demands, such as that of the sawmill. The decision variables in both of the alternative b-IGCC process configurations are the maximum cycle pressure and temperature of the steam Rankine cycle and the mass flow rate of the water/steam that remains in the combined heat and power (CHP) system. The only difference in the settings of the optimization problem between the two process configurations is that an additional constraint is introduced in the alternative without the DH system, so that the amount of steam condensed at 1.9 bar is exactly the one required to satisfy the sawmill heat demand.

\subsection{Thermodynamic Indicators}

The energy indicators of the SNG and b-IGCC process configurations are evaluated according to Equations (1)-(4). The system boundaries and energy flows used to define the indicators are illustrated in Figure 1. The indicator in Equation (1) compares the energy associated with the BFM input to the gasifier to the chemical energy of the final bio-SNG output, and it is often referred to as the cold gas efficiency. It is worth noting that the denominator of this indicator accounts only for the biomass by-products entering the gasifier. Equation (2) represents the overall energy efficiency of the bio-SNG process by accounting for all of the major flows crossing system boundaries; see Figure 2. Equations (3) and (4) measure the overall energy efficiency of the b-IGCC process with and without the DH option, respectively.

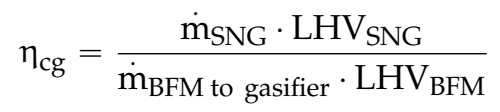

$$
\begin{aligned}
& \eta_{\mathrm{en}, \mathrm{SNG}}=\frac{\dot{\mathrm{m}}_{\mathrm{SNG}} \cdot \mathrm{LHV}_{\mathrm{SNG}}+\dot{\mathrm{Q}}_{\mathrm{th}, \text { sawmill }}+\dot{\mathrm{W}}_{\mathrm{el}, \text { net }}}{\dot{\mathrm{m}}_{\mathrm{BMF}} \cdot \mathrm{LHV}_{\mathrm{BMF}}} \\
& \eta_{\mathrm{en}, \mathrm{b}-\mathrm{IGCC}+\mathrm{DH}}=\frac{\dot{\mathrm{W}}_{\mathrm{el}, \mathrm{net}}+\dot{\mathrm{Q}}_{\mathrm{th}, \text { sawmill }}+\dot{\mathrm{Q}}_{\mathrm{DH}}}{\dot{\mathrm{m}}_{\mathrm{BMF}} \cdot \mathrm{LHV}_{\mathrm{BMF}}} \\
& \eta_{\text {en,b-IGCC }}=\frac{\dot{\mathrm{W}}_{\mathrm{el}, \mathrm{net}}+\dot{\mathrm{Q}}_{\mathrm{th}, \text { sawmill }}}{\dot{\mathrm{m}}_{\mathrm{BMF}} \cdot \mathrm{LHV}_{\mathrm{BMF}}}
\end{aligned}
$$




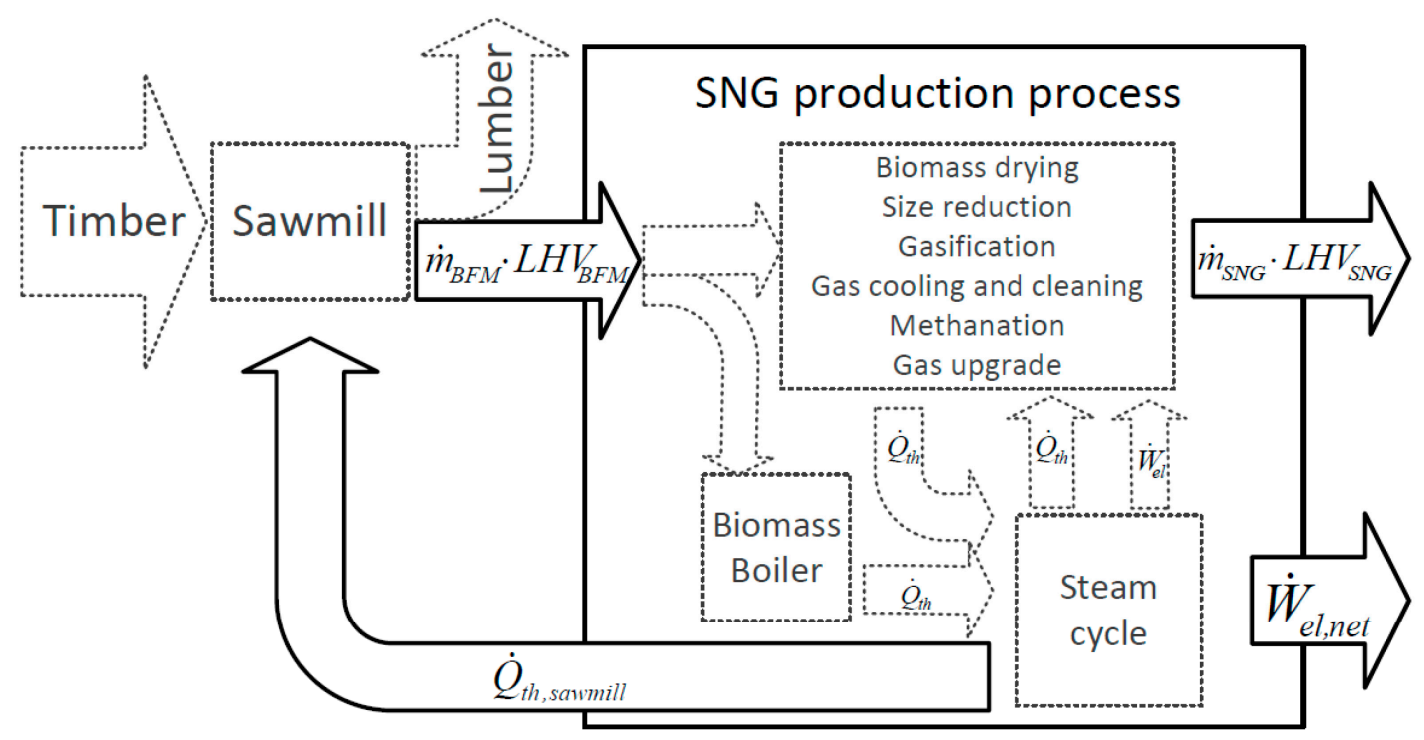

(a)

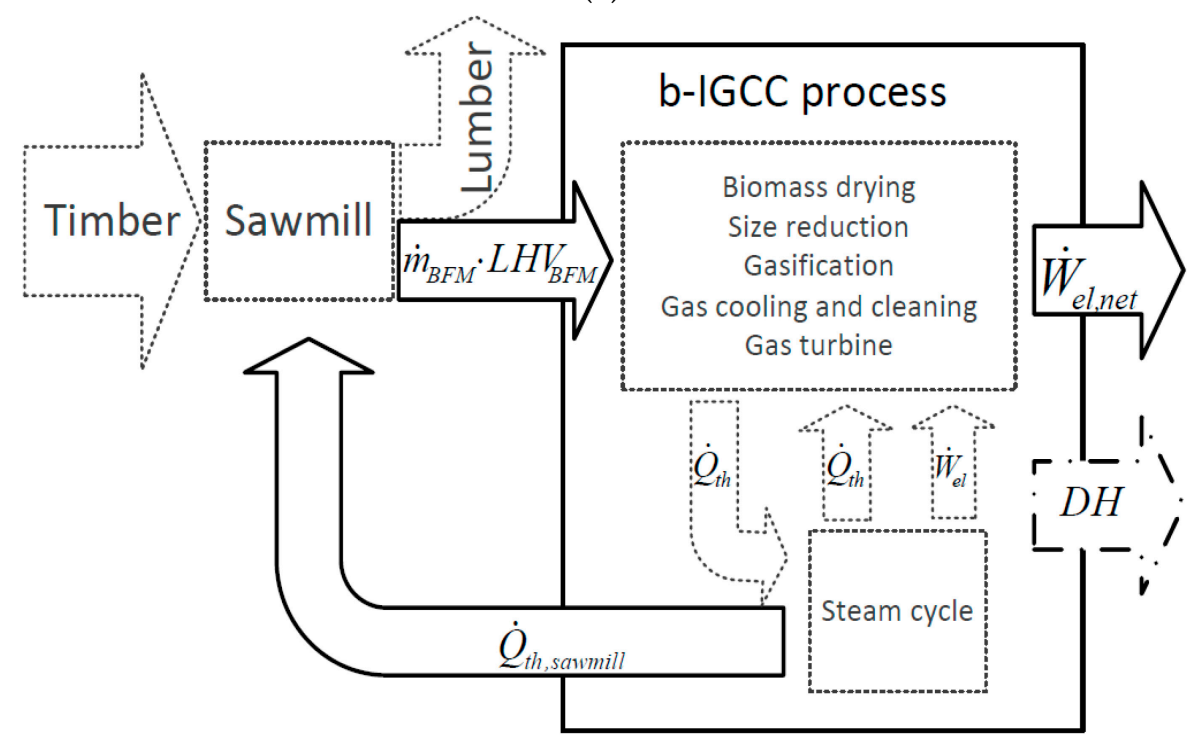

(b)

Figure 2. System boundaries used for evaluating the thermodynamic and economic indicators: bio-SNG process (a) and b-IGCC process (b).

The three process configurations are also evaluated according to their overall exergy efficiencies, using Equations (5)-(7). In the b-IGCC process alternative with the DH system, it is assumed that the thermal energy supplied to the DH system could be converted into electricity with a thermal efficiency equal to $10 \%$.

$$
\begin{gathered}
\eta_{\mathrm{ex}, \mathrm{SNG}}=\frac{\dot{\mathrm{m}}_{\mathrm{SNG}} \cdot \mathrm{e}_{\mathrm{SNG}}+\dot{\mathrm{W}}_{\mathrm{el}, \mathrm{net}}}{\dot{\mathrm{m}}_{\mathrm{BMF}} \cdot \mathrm{e}_{\mathrm{BMF}}} \\
\eta_{\mathrm{ex}, \mathrm{b}-\mathrm{IGCC}+\mathrm{DH}}=\frac{\dot{\mathrm{W}}_{\mathrm{el}, \mathrm{net}}+\eta_{\mathrm{ex}, \mathrm{DH} \rightarrow \mathrm{el}} \cdot \dot{\mathrm{Q}}_{\mathrm{DH}}}{\dot{\mathrm{m}}_{\mathrm{BMF}} \cdot \mathrm{e}_{\mathrm{BMF}}} \\
\eta_{\mathrm{ex}, \mathrm{b}-\mathrm{IGCC}}=\frac{\dot{\mathrm{W}}_{\mathrm{el}, \mathrm{net}}}{\dot{\mathrm{m}}_{\mathrm{BMF}} \cdot \mathrm{e}_{\mathrm{BMF}}}
\end{gathered}
$$




\subsection{Economic Indicators}

The economic evaluation is performed by taking into account the operating costs and the investment costs for the equipment that is involved in the flowsheet of the processes. The capital investment is estimated by evaluating the cost of each component in the major process equipment from literature data according to its size. All cost values are updated to the Euro value of 2013. Commodity prices are those of the last quarter of 2013, and exchange rates used for currency conversions (i.e., $8.86 \mathrm{SEK} / €$ and $6.43 \mathrm{SEK} / \$$ ) are those of the same period. Two approaches have been adopted for estimating the total capital investment.

The cost associated with the process units that have been designed in detail in this study (such as the heat exchanger network (HEN), turbomachinery, steam cycle components and methanation reactors) is estimated according to [24]. The installed cost $\left(C_{i n}\right)$ of process equipment can be correlated to the bare module cost by Equation (8):

$$
\mathrm{C}_{\mathrm{in}, \mathrm{i}}=\left(1+\mathrm{f}_{1}\right) \cdot \mathrm{C}_{\mathrm{BM}, i}+\mathrm{f}_{2} \cdot \mathrm{C}_{\mathrm{BM}, i}^{0}
$$

where $\mathrm{C}_{\mathrm{BM}, i}$ and $\mathrm{C}_{\mathrm{BM}, i}^{0}$ represent the bare module cost of equipment $i$ evaluated in the actual process operating conditions and in the base case conditions (i.e., ambient pressure and carbon steel construction), respectively. Coefficient $f_{1}$ accounts for contingency and fee costs depending on the reliability of cost data and completeness of the process flowsheet. A value of $18 \%$ is used ( $15 \%$ and $3 \%$ of the bare module cost in the actual operating conditions for contingency and fee costs, respectively [24]). Coefficient $\mathrm{f}_{2}$ accounts for the costs related to site development, auxiliary building and utilities. A value of $50 \%$ of the bare module cost in the base case conditions is assumed [24]. Further information on the relationships between the equipment bare module cost and purchase cost can be found in Appendix A.

The capital cost of the HEN is estimated from the mass flow rates and the temperatures of the thermal streams in the black box of the HEATSEP method, as they result from the optimization of the process configurations. The loads of the heat exchangers are determined by matching the streams according to the hot and cold composite curves. The area of heat exchangers and then the cost are determined by applying appropriate heat transfer coefficients (depending on the nature of the streams) and minimum temperature differences $\left(\Delta \mathrm{T}_{\min }\right)$ that would result in a reasonable heat transfer area for any match among the streams.

The cost associated with the remaining major process units (such as biomass pretreatment, gasification, gas cleaning and bio-SNG upgrading) are estimated by scaling published data using the power law of capacity. The reference costs and sizes used for estimating the purchase cost of these process units are documented in Table A1. The actual equipment purchase cost of a single component is first estimated using the power law of capacity by scaling it from a similar component with known cost and size according to a scaling exponent. The equipment purchase cost is then multiplied by an overall installation factor (also presented in Table A1) to obtain the installed cost of the process unit. In this case, the installed equipment cost is related to the purchase cost according to Equation (9):

$$
\mathrm{C}_{\mathrm{in}, j}=\mathrm{f}_{j} \mathrm{C}_{\mathrm{E}, j}
$$

where $\mathrm{f}_{j}$ and $\mathrm{C}_{\mathrm{E}, j}$ represent the overall installation factor and equipment purchase cost, respectively. The capital investment (CI) is then calculated using Equation (10) as the sum of Equations (8) and (9). The bare module equipment costs are estimated based on sizing parameters and cost factors reported in Table A2.

$$
\mathrm{CI}=\left[1.18 \sum_{i=1}^{n} \mathrm{C}_{\mathrm{BM}, i}+0.5 \sum_{i=1}^{n} \mathrm{C}_{\mathrm{BM}, i}^{0}\right]+\sum_{j=1}^{m} \mathrm{f}_{j} \mathrm{C}_{\mathrm{E}, j}
$$


The internal rate of return (IRR) on the investment is evaluated as the economic indicator for the considered cases. Table 1 presents a list of the market prices and the other economic parameters that have been assumed.

Table 1. Market price and other economic parameters used in the evaluation of the IRR.

\begin{tabular}{|c|c|c|}
\hline Parameter & Unit & Value \\
\hline Investment interest rate & $\%$ & 4 \\
\hline Economic life time & Year & 20 \\
\hline Annual operational time $\left(t_{o p}\right)$ & Hour & 8000 \\
\hline Operators ${ }^{a}$ & p. ${ }^{b} /$ shift & 6 \\
\hline Operator salary & $€ /(\mathrm{p} \cdot$ year $)$ & 55,000 \\
\hline Maintenance cost $\left(\mathrm{C}_{\mathrm{om}}\right)$ & $\%$ of $\mathrm{CI}$ & 5 \\
\hline BFM price $\left(\mathrm{C}_{\mathrm{BFM}}\right)^{\mathrm{c}}$ & $€ / \mathrm{MWh}_{\mathrm{LHV}}$ & 22 \\
\hline Electricity $\left(\mathrm{C}_{\mathrm{el}}\right)$ (including $\mathrm{CO}_{2}$ charge $)^{\mathrm{c}}$ & $€ / \mathrm{MWh}_{\mathrm{el}}$ & 68 \\
\hline Natural gas (including $\mathrm{CO}_{2}$ charge) ${ }^{\mathrm{c}}$ & $€ / \mathrm{MWh}_{\mathrm{LHV}}$ & 48 \\
\hline District heating thermal energy ${ }^{c}$ & $€ / \mathrm{MWh}_{\mathrm{th}}$ & 35 \\
\hline $\mathrm{CO}_{2}$ charge (input) ${ }^{\mathrm{c}}$ & $€ / \mathrm{tCO}_{2}$ & 36 \\
\hline Renewable electricity policy support ${ }^{\mathrm{c}}$ & $€ / \mathrm{MWh}_{\mathrm{el}}$ & 7 \\
\hline Tax on profit & $\%$ & 22 \\
\hline
\end{tabular}

a Full time operation requires 4 shifts per day; ${ }^{b}$ personnel (p.) for the largest sawmill size; for the other sizes, an exponent equal to 0.7 is used to scale down operator salary costs; ${ }^{c}$ price levels represent the Swedish market in 2013 [25].

\section{Results and Discussion}

\subsection{Integrated Grand Composite Curves of the Three Configurations}

Figures 3 and 4 present the integrated grand composite curves of the three process configurations for the largest sawmill size. The distinctive features of the bio-SNG configuration (Figure 3, red curve) are the radiative heat from the biomass boiler (the horizontal segment at $850{ }^{\circ} \mathrm{C}$ ) and the demand for process steam generation at about $310^{\circ} \mathrm{C}$ (which is the same as the temperature level of the upper horizontal segment of the blue curve). In order to maximize the BFM input to the bio-SNG process, the amount of steam generated in the steam cycle is just enough to satisfy the heat deficit and steam demand of the integrated industrial site (sawmill plus bio-SNG process); see Section 3.1 for further details.

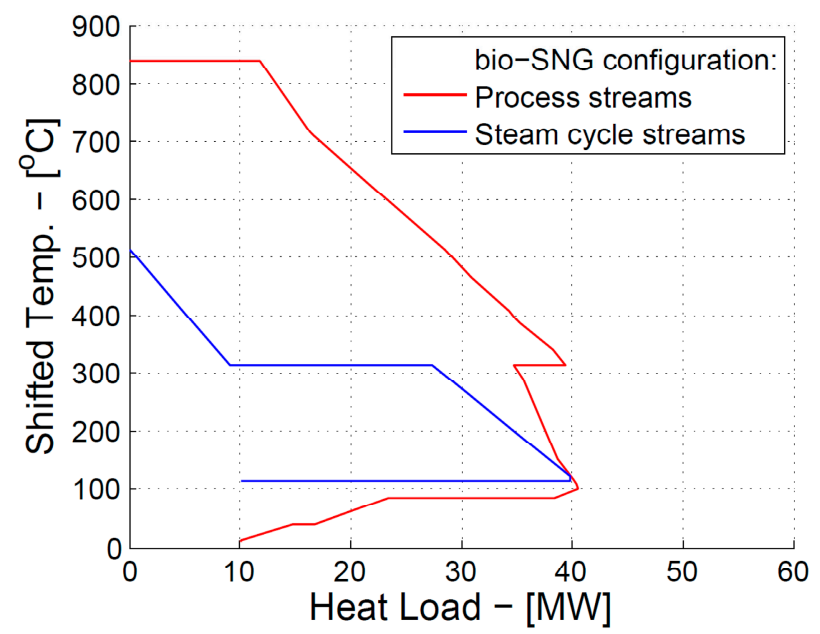

Figure 3. Integrated grand composite curves of the bio-SNG configuration for the largest sawmill size. 


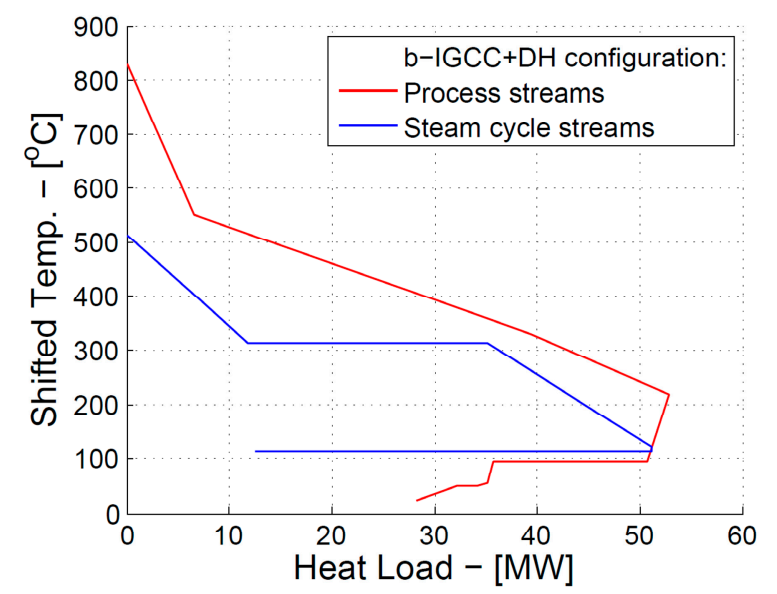

(a)

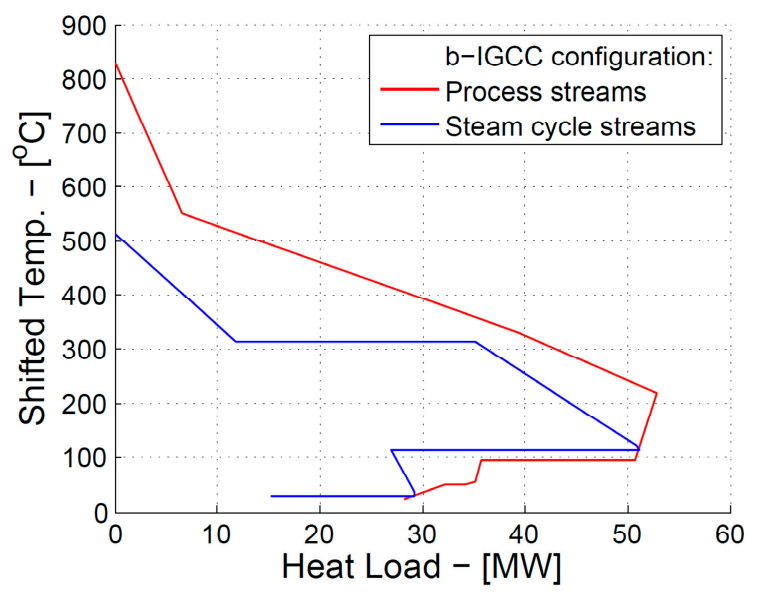

(b)

Figure 4. Integrated grand composite curves of the b-IGCC configuration with DH (a) and without DH (b) for the largest sawmill size.

The heat pockets in the red curves of the b-IGCC configuration (Figure 4) are mainly a result of product gas cooling (from $850^{\circ} \mathrm{C}$ ), the recovery of heat from the exhaust gases of the gas turbine (from $550{ }^{\circ} \mathrm{C}$ ) and the thermal demand of the sawmill (at $75^{\circ} \mathrm{C}$ ). In both cases, the steam Rankine cycle exploits these pockets for generating steam (the three upper segments of the blue curves) and satisfies the heat demands of the sawmill (and that of the DH system in Figure 4a) in the lower temperature range using condensing steam (the lower horizontal segment of the blue curves). The blue curve in Figure $4 \mathrm{~b}$ also shows a further steam condensation level that follows the additional expansion in the condensing turbine. A detailed discussion regarding b-IGCC in the context of integrated forest industries can be found in [26].

\subsection{Energetic Perspective}

The magnitudes of the energy streams of the bio-SNG process configuration, defined according to the system boundaries shown in Figure 2, are summarized in Table 2 for all of the considered sawmill sizes. In order to reflect on the thermodynamic performance of the bio-SNG process, a generic evaluation of the process flowsheet is presented in Table B1 (description of streams) and Table B2 (thermodynamic state and compositions of streams).

Table 2. Energy streams and indicators of the bio-SNG process configuration for the different sawmill sizes.

\begin{tabular}{|c|c|c|c|c|c|c|c|c|}
\hline \multirow{2}{*}{$\frac{\text { Parameter }}{\text { Annual lumber production }}$} & \multirow{2}{*}{$\frac{\text { Unit }}{10^{3} \mathrm{~m}^{3}}$} & \multicolumn{7}{|c|}{ Sawmill Sizes } \\
\hline & & 400 & 283 & 212 & 141 & 106 & 71 & 53 \\
\hline BFM available & $\mathrm{MW}_{\mathrm{LHV}}$ & 122.9 & 86.85 & 65.13 & 43.42 & 32.57 & 21.71 & 16.28 \\
\hline BFM to biomass boiler & $\%$ & 42.99 & 42.93 & 42.99 & 43.19 & 43.27 & 42.88 & 42.23 \\
\hline SNG production & $\mathrm{MW}_{\mathrm{LHV}}$ & 45.23 & 31.99 & 23.98 & 15.94 & 11.95 & 8.05 & 6.13 \\
\hline Sawmill thermal load & $\mathrm{MW}_{\mathrm{th}}$ & 16.91 & 11.95 & 8.96 & 5.98 & 4.48 & 2.99 & 2.24 \\
\hline Cold gas efficiency (Equation (1)) & $\%$ & 64.55 & 64.54 & 64.56 & 64.61 & 64.66 & 64.95 & 65.12 \\
\hline Wobbe index & $\mathrm{MJ} / \mathrm{Nm}^{3}$ & 44.96 & 44.87 & 44.74 & 44.48 & 44.18 & 42.36 & 41.49 \\
\hline Power generation & $\mathrm{MW}_{\mathrm{el}}$ & 11.34 & 7.54 & 5.57 & 3.66 & 2.71 & 1.67 & 1.14 \\
\hline Power consumption & $\mathrm{MW}_{\mathrm{el}}$ & 4.46 & 3.15 & 2.36 & 1.57 & 1.17 & 0.78 & 0.59 \\
\hline Net power export & $\mathrm{MW}_{\mathrm{el}}$ & 6.88 & 4.39 & 3.21 & 2.10 & 1.54 & 0.89 & 0.55 \\
\hline Energy efficiency (Equation (2)) & $\%$ & 56.17 & 55.65 & 55.50 & 55.30 & 55.17 & 54.98 & 54.77 \\
\hline Exergy efficiency (Equation (5)) & $\%$ & 42.40 & 41.88 & 41.74 & 41.54 & 41.41 & 41.22 & 41.01 \\
\hline
\end{tabular}

The magnitude of the energy output streams of the b-IGCC process configurations are presented in Figure 5 for all of the considered sawmill sizes and for both configuration alternatives (with and 
without DH systems). It appears that the power production in the b-IGCC configuration without $\mathrm{DH}$ is higher than that in the other configuration. This is expected since the steam that is condensed to supply heat to the $\mathrm{DH}$ in one alternative is expanded in a condensing steam turbine to generate additional power in the other. In both b-IGCC configuration alternatives, the heat provided to satisfy the sawmill demand is represented as a negative contribution to indicate that it is a constraint that must be satisfied.

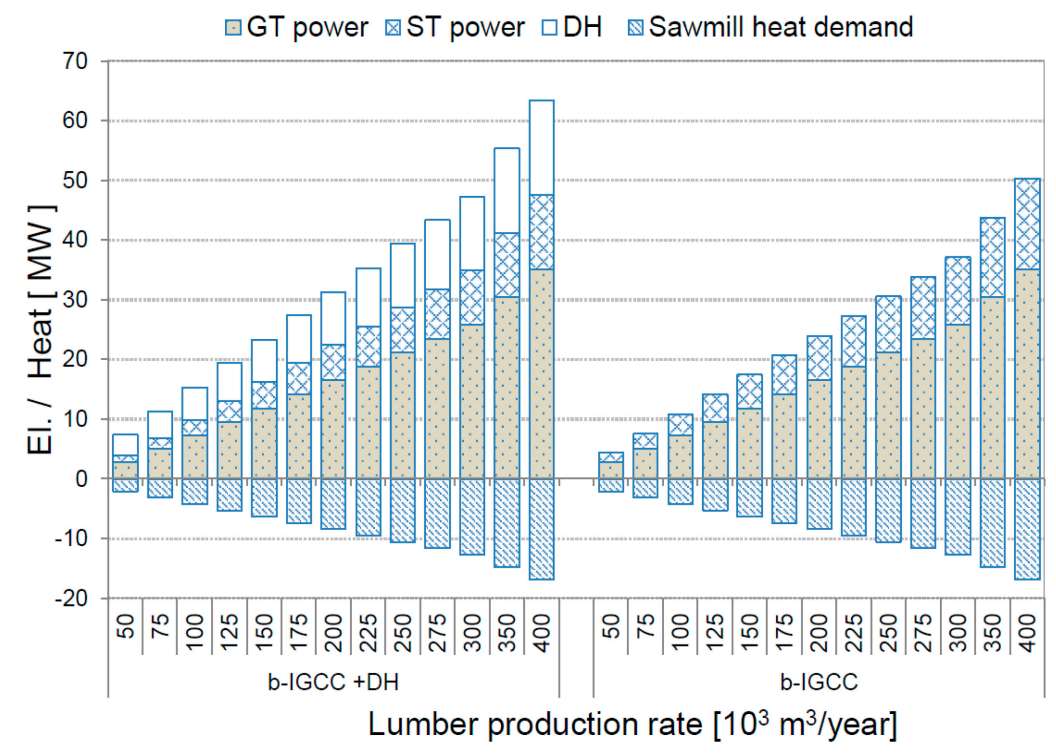

Figure 5. Energy streams (electricity (El.) from gas turbine (GT) and steam turbine (ST), heat to the DH system, heat to the sawmill) of the b-IGCC process configurations as a function of sawmill size.

The overall energy efficiencies of the considered process configurations (defined by Equations (2)-(4)) are compared in Figure 6a as a function of sawmill size. It appears that the b-IGCC configuration with the DH system results in the highest overall energy efficiency $(62 \%-66 \%$, increasing with sawmill size), followed by the bio-SNG process configuration (about $55 \%-56 \%$ for all of the sawmill sizes considered). The b-IGCC configuration without the DH system has always the lowest overall efficiency (from $43 \%-55 \%$, increasing with sawmill size).

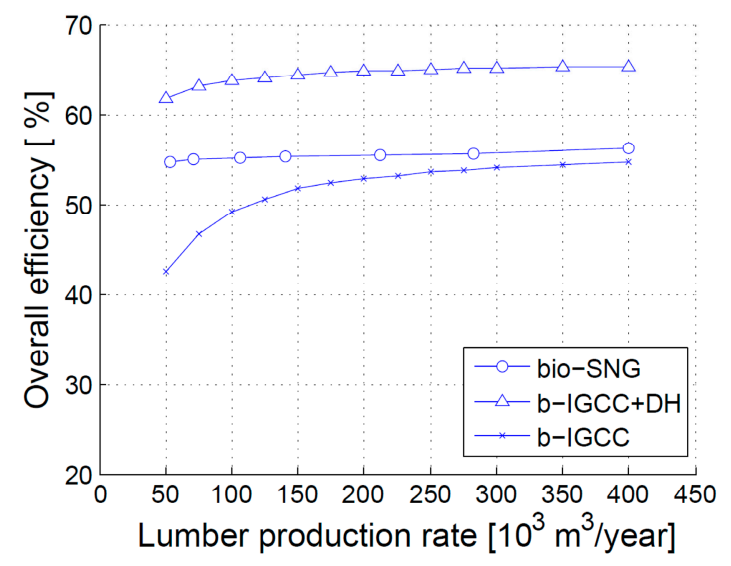

(a)

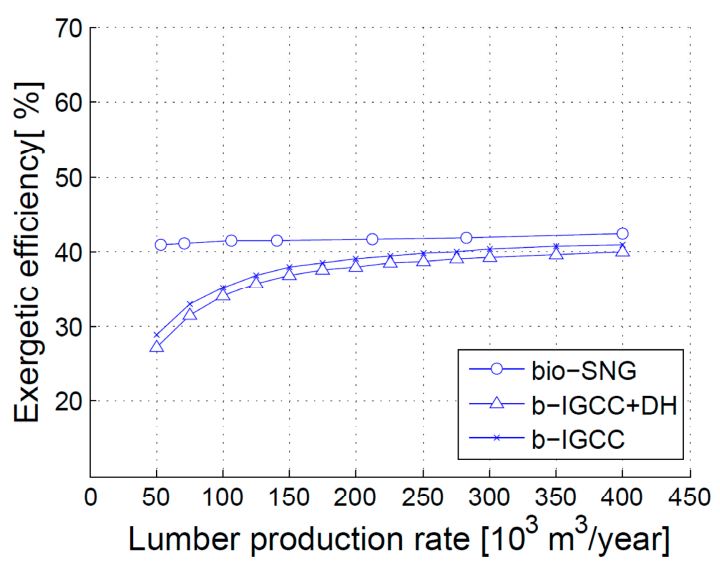

(b)

Figure 6. Overall energy (a) and exergy (b) efficiencies of the different process configurations.

Figure $6 \mathrm{~b}$ compares the exergy efficiencies of the considered process configurations, as defined by Equations (5)-(7). It appears that the ranking of the three process configurations is completely changed: 
the highest exergy efficiency is that of the bio-SNG configuration $(41 \%-42 \%$, with increasing efficiency as the sawmill size increases), then the b-IGCC configuration without the DH system $(30 \%-41 \%$, increasing with sawmill size) and, finally, the b-IGCC configuration with the DH system $(29 \%-40 \%$, increasing with sawmill size).

It is worth noting that the b-IGCC configuration with the DH system has the highest energy efficiency and the lowest exergy efficiency because of the low temperature heat output, which is a big amount in terms of energy, but not significant in terms of exergy (the exergy of the electric output from the condensing turbine is higher).

\subsection{Economic Perspective}

Figure 7 shows how the capital cost shares of the different sections in the bio-SNG process configuration change as the size of the sawmill is varied. For a sawmill annual lumber production greater than $71,000 \mathrm{~m}^{3}$, the investment is largely dominated by the cost of the gasification process (23\%-35\%, with an increasing share as the sawmill size increases). For sawmill annual lumber production capacities lower than $71,000 \mathrm{~m}^{3}$, the share associated with the HEN dominates the capital cost $(10 \%-30 \%$, with an increasing share as the sawmill size decreases). The shares of the other sections are generally lower: gas conditioning and upgrade $13 \%-18 \%$ each, with an increasing share as sawmill size increases; methanation 3\%-9\%, with an increasing share as sawmill size increases; steam section and pretreatment, about $5 \%$ each.

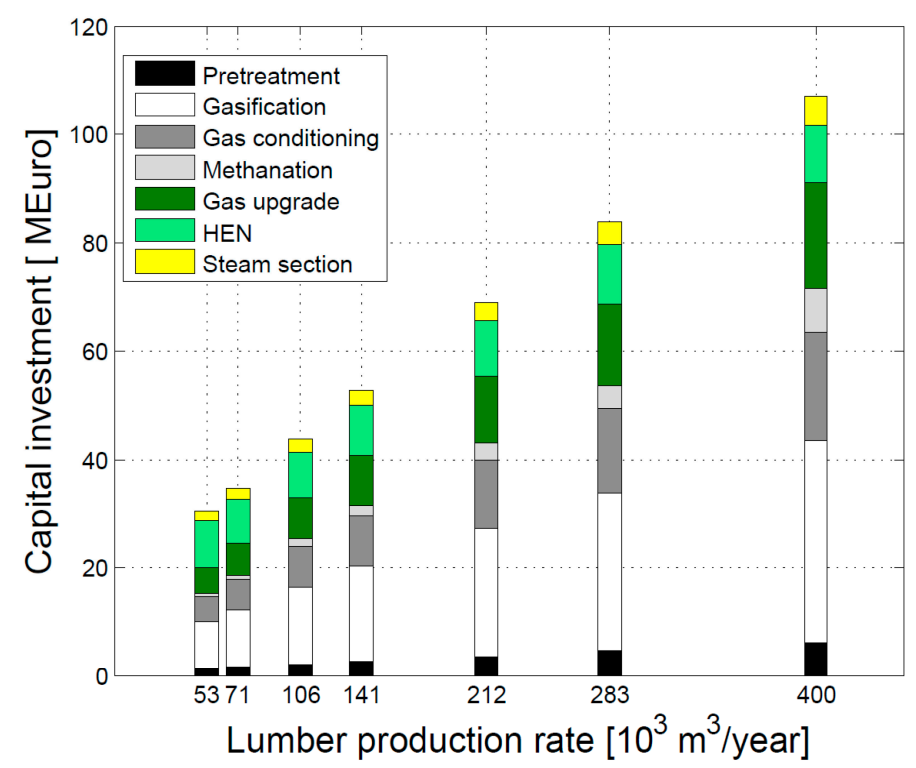

Figure 7. Capital cost share of the different sections of the bio-SNG process configuration.

Bio-SNG and electricity selling prices that would allow one to obtain the imposed IRR values of $4 \%, 8 \%$ and $12 \%$ are calculated backwards. Thermal energy for district heating in the b-IGCC + DH case and electricity in the bio-SNG case are considered as by-products and sold at the current market price. The results are presented in Figure 8. The ranges for the market price of natural gas required to meet the imposed IRR values are 77-123€/MWh (4\%), 87-146€/MWh (8\%) and 99-171 €/MWh (12\%), the lower values being of course obtained with the larger sawmills. A policy supporting biofuels is therefore required to make the bio-SNG process configuration profitable, but it also appears that in any case, a subsidy would not be reasonable for the sawmill sizes below 106,000 $\mathrm{m}^{3}$ of lumber per year due to the economy-of-scale effects. For example, biofuel subsidy certificates in the range of $28-52 € / M W h$ (decreasing as sawmill size increases) are required in order to break-even (4\% IRR) for the bio-SNG processes integrated with a sawmill having an annual lumber production greater than 
$106,000 \mathrm{~m}^{3}$. The subsidy levels estimated here are generally higher compared to previous studies. In $[27,28], 24-42 € /$ MWh was reported for similar processes, but with considerably larger biomass input (150-400 MW compared to 20-125 MW in this work). Of course, this difference can be explained by the different economy-of-scale, which plays a role in reducing the levels of required subsidy.

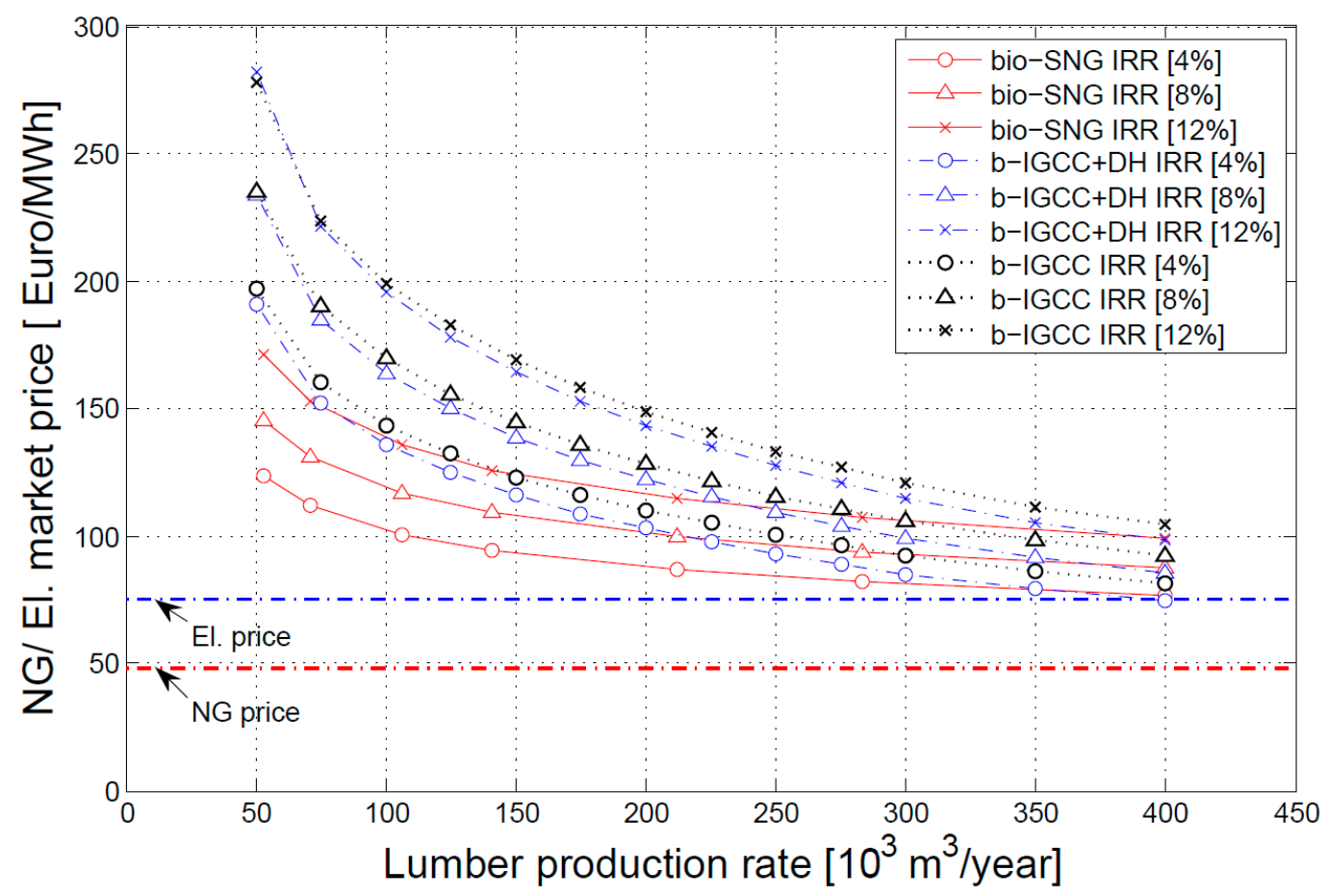

Figure 8. Market price of NG/electricity in order to meet the imposed IRR values.

Should future policy measures allow the biogenic $\mathrm{CO}_{2}$ separated during gas upgrading to be included in the emission trading system, additional income can be obtained in the form of emission certificates. For example, additional income in the range of 4-6€/MWh of bio-SNG produced (increasing with sawmill size) can be achieved by assuming that the benefit from the biogenic $\mathrm{CO}_{2}$ sequestration certificates is equal to the penalty for fossil $\mathrm{CO}_{2}$ emission charges and by deducting the $\mathrm{CO}_{2}$ transportation (13€/tCO 2 [29]) and storage $\left(9 € / \mathrm{tCO}_{2}[29]\right)$ expenses.

In the b-IGCC configuration alternative with $\mathrm{DH}$, the ranges for the electricity market price required to meet the imposed IRR values are 74-191 $€ /$ MWh (4\%), 85-234 $€ /$ MWh $(8 \%)$ and $98-282 € / \mathrm{MWh}(12 \%)$. In the alternative without $\mathrm{DH}$, they become $82-197 € / \mathrm{MWh}(4 \%)$, 92-235 $€ / \mathrm{MWh}(8 \%)$ and 104-278 $€ / \mathrm{MWh}(12 \%)$. Apparently, the b-IGCC alternative with DH results in lower values of market prices for electricity compared to the alternative without DH. This is because the amount of heat provided to the $\mathrm{DH}$ system is relatively large compared to the size of the sawmill. For example, about 0.13 TWh would be provided annually to a DH system with the largest sawmill size. However, it could be a problem, if not impossible, to find a market for this waste heat if the location of sawmills were inconvenient for $\mathrm{DH}$ consumers and in the case of large seasonal fluctuations of the DH demand.

\section{Conclusions}

The energetic and economic perspectives were investigated regarding the integration of different biomass gasification-based technologies for upgrading sawmill by-products on-site. The main focus was on whether, or under what conditions, the investment in a plant producing bio-SNG from sawmill by-products is economically viable. The option of utilizing sawmill by-products in a b-IGCC 
configuration to produce electricity (and heat for a DH system in one alternative) was also explored for comparison.

With a limited availability of relatively low cost BFM, it is essential to choose between the production of bio-SNG and that of electricity/heat. If the production of bio-SNG is prioritized, perhaps in order to support the utilization of biofuels in the transport sector, large-scale plants (i.e., sawmills having an annual lumber production greater than 106,000 $\mathrm{m}^{3}$ ) with ambitious biofuel subsidy requirements ( $28-52 € / \mathrm{MWh}$ ) are to be favored. In a less ambitious biofuel subsidy scenario, the b-IGCC configuration with the DH system is more attractive compared to the alternative without the $\mathrm{DH}$ system, although both cases resulted in a cost for electricity production that is higher than its market value.

Acknowledgments: The authors would like to thank Bio4Energy, a strategic research environment appointed by the Swedish government, for supporting this work.

Author Contributions: Mesfun and Umeki designed the process configurations and developed the mathematical models with data input from Anderson regarding Nordic sawmills. Mesfun and Toffolo performed the process integration and optimization analyses. All authors contributed to the preparation of the manuscript.

Conflicts of Interest: The authors declare no conflict of interest.

\begin{tabular}{|c|c|}
\hline \multicolumn{2}{|c|}{ Abbreviations } \\
\hline A & Equipment sizing parameter \\
\hline BFM & Biomass fuel mix \\
\hline b-IGCC & Biomass integrated gasification combined cycle \\
\hline bio-SNG & Biomass-based synthetic natural gas \\
\hline CEPCI & Chemical engineering plant cost index \\
\hline CI & Capital investment \\
\hline $\mathrm{D}$ & Reactor vessel diameter \\
\hline $\mathrm{DH}$ & District heat \\
\hline $\mathrm{HEN}$ & Heat exchanger network \\
\hline IRR & Internal rate of return \\
\hline LHV & Lower heating value \\
\hline $\mathrm{P}$ & Operating pressure (bar) \\
\hline RES & Renewable energy sources \\
\hline SNG & Synthetic/substitute natural gas \\
\hline \multicolumn{2}{|r|}{ ( } \\
\hline$i$ & $\begin{array}{l}\text { Set of equipment for which cost estimates are made based on } \\
\text { the module costing method. }\end{array}$ \\
\hline$j$ & $\begin{array}{l}\text { Set of equipment for which cost estimates are recalculated based on } \\
\text { the published cost data or in-house database. }\end{array}$ \\
\hline \multicolumn{2}{|r|}{${ }^{1}$} \\
\hline $\mathrm{C}_{\mathrm{BM}, i}$ & Bare module cost of equipment $i$ calculated at the actual process conditions \\
\hline $\mathrm{C}_{\mathrm{BM}, i}^{0}$ & Bare module cost of equipment $i$ calculated at the base rating \\
\hline $\mathrm{C}_{\mathrm{E}, j}$ & Cost of equipment $j$ recalculated from the data in Table A1 \\
\hline $\mathrm{C}_{\mathrm{p}, i}^{\mathrm{o}}$ & $\begin{array}{l}\text { Purchase cost of equipment } i \text { calculated according to the module costing } \\
\text { method at the base rating }\end{array}$ \\
\hline$f_{B M}$ & Bare module factor \\
\hline $\mathrm{f}_{j}$ & Overall installation factor of equipment $j$ \\
\hline $\mathrm{f}_{\mathrm{m}}$ & Equipment construction material factor \\
\hline $\mathrm{f}_{\mathrm{p}}$ & Pressure factor \\
\hline$\Delta \mathrm{T}_{\min }$ & Minimum temperature difference \\
\hline \multicolumn{2}{|c|}{ Coefficients } \\
\hline $\mathrm{B}$ & Coefficients for evaluating the bare module factor \\
\hline $\mathrm{C}$ & Coefficients for evaluating the pressure factor \\
\hline $\mathrm{K}$ & Coefficients for estimating the equipment cost at the base rating \\
\hline
\end{tabular}




\section{Appendix A}

\section{Equipment Purchase Cost Data}

Table A1. Reference size parameter used for estimating purchased equipment cost.

\begin{tabular}{|c|c|c|c|c|c|}
\hline Unit & $\begin{array}{l}\text { Original Unit } \\
\operatorname{Cost}^{\mathrm{a}}\left(\mathrm{ME}_{2013}\right)\end{array}$ & $\begin{array}{c}\text { Reference Size } \\
\text { Parameter }\end{array}$ & $\begin{array}{l}\text { Installation } \\
\text { Factor }{ }^{\mathbf{b}} \mathbf{f}_{j}\end{array}$ & $\begin{array}{c}\text { Scaling } \\
\text { Exponent }^{c}\end{array}$ & Reference \\
\hline \multicolumn{6}{|l|}{ Biomass Handling } \\
\hline Conveyor & 0.36 & $33.5 \mathrm{ton} / \mathrm{h}$ & 2 & 0.8 & {$[5,30]$} \\
\hline Belt conveyor dryer ${ }^{\mathrm{d}}$ & 2.20 & $959,000 \mathrm{~m}^{3} / \mathrm{h}$ (air) & 2 & 0.8 & [31] \\
\hline Grinding & 0.35 & 33.5 ton $/ \mathrm{h}$ & 2 & 0.6 & {$[5,30]$} \\
\hline Feeding system & 0.43 & 33.5 ton $/ \mathrm{h}$ & 2 & 1.0 & {$[5,30]$} \\
\hline \multicolumn{6}{|l|}{ Gasification } \\
\hline Direct gasifier (BFB) ${ }^{\mathrm{e}}$ & 40.8 & $358 \mathrm{MW}_{\text {th }}(\mathrm{LHV})$ & 2 & 0.72 & [30] \\
\hline ASU & 25.7 & 576 ton $\mathrm{O}_{2} /$ day & 1.5 & 0.75 & [30] \\
\hline \multicolumn{6}{|l|}{ Gas Cleaning } \\
\hline Hot gas cleaning & 31.3 & $74.1 \mathrm{~m}^{3} / \mathrm{s}$ gas flow & 1.86 & 1.0 & {$[5,30]$} \\
\hline Fabric filter & 0.72 & $15.6 \mathrm{~m}^{3} / \mathrm{s}$ gas flow & 1.86 & 0.7 & {$[5,30]$} \\
\hline Water scrubber & 2.76 & $12.1 \mathrm{~m}^{3} / \mathrm{s}$ gas flow & 1.86 & 0.7 & {$[5,30]$} \\
\hline Acid gas removal unit & 6.92 & $1.31 \mathrm{~m}^{3} / \mathrm{s}$ gas flow & 1.86 & 0.7 & {$[5,30]$} \\
\hline Guard Bed & & & & & \\
\hline Activated carbon bed & 0.025 & $8 \mathrm{Nm}^{3} / \mathrm{s}$ gas flow & 3 & 1.0 & [30] \\
\hline
\end{tabular}

Methanation (ICI)

Reactor $1^{\mathrm{f}}$

Reactor $2^{\mathrm{f}}$

Reactor $3^{f}$

Catalyst material $\mathrm{g}$

Cost of reactor vessels, excluding heat exchangers and catalyst material. Prices are estimated according to the module costing method.

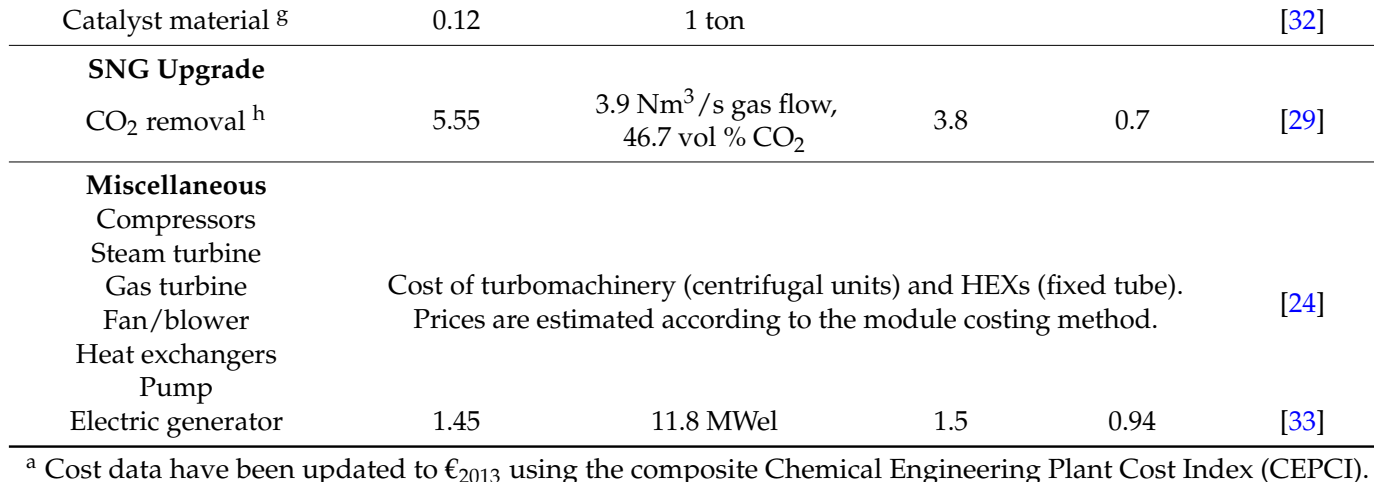

a Cost data have been updated to $€_{2013}$ using the composite Chemical Engineering Plant Cost Index (CEPCI). In case the original unit cost has not been given in $€$, the currency is first converted to $€$ by using the exchange rate of the year in which the money value is reported and then adjusted to the value of $\epsilon_{2013}$ by applying the CEPCI. ${ }^{b}$ Overall installation factor for equipment $j$. It includes auxiliary equipment and installation labor, engineering and contingencies. Unless values are given by the literature, the overall installation factor is set to 2 for a $70 \mathrm{MW}_{\mathrm{th}}$ scale [5]. ${ }^{\mathrm{c}}$ Cost scaling is performed using the power law of capacity. ${ }^{\mathrm{d}}$ Original equipment cost is estimated using a wet biomass loading of $30 \mathrm{~kg} / \mathrm{m}^{2}$ of belt area at a loading rate of $10 \mathrm{~kg} / \mathrm{s}$ and a drying time $(\tau)$ of $2500 \mathrm{~s}$, according to the correlations reported in [31]. It is further assumed that the dryer belt is $10 \mathrm{~m}$ wide and that the cover is $6 \mathrm{~m}$ high. The scaling exponent is adopted from [30]. ${ }^{e}$ Estimated cost of complete gasifier installation according to the National Renewable Energy Laboratory (NREL) report [34]. The scaling exponent is adopted from [30]. ${ }^{\mathrm{f}}$ Original cost calculated from module costing in $\$_{2001}$ [24]. Methanation reactors are considered vertical vessels, the diameter being calculated using a mean superficial gas velocity of $0.14 \mathrm{~m} / \mathrm{s}$, with maximum vessel diameter not to exceed $4 \mathrm{~m}$. Vessel height is calculated from a regression of the correlation in [12] for fluidized bed methanation reactors. ${ }^{\mathrm{g}}$ Catalyst material cost is calculated according to the correlated data in [32], assuming a space velocity of $4.5 \mathrm{Nm}^{3} /$ (kg-catalyst. $\mathrm{h}$ ) and using an updated specific catalyst cost of $107 €_{2013} / \mathrm{kg}$. ${ }^{\mathrm{h}}$ The original equipment cost of monoethanolamine (MEA) is estimated based on the $€_{2010}$ cost estimate of the amine-absorption unit that includes the absorber, stripper, condenser, reboiler, HEXs and pumps. Heyne [29] has studied three different $\mathrm{CO}_{2}$ separation technologies, and amine-absorption is reported to be the best for the overall bio-SNG process economy. A scaling exponent of 0.7 is used [30]. 
Table A2. Factors used for module costing [24].

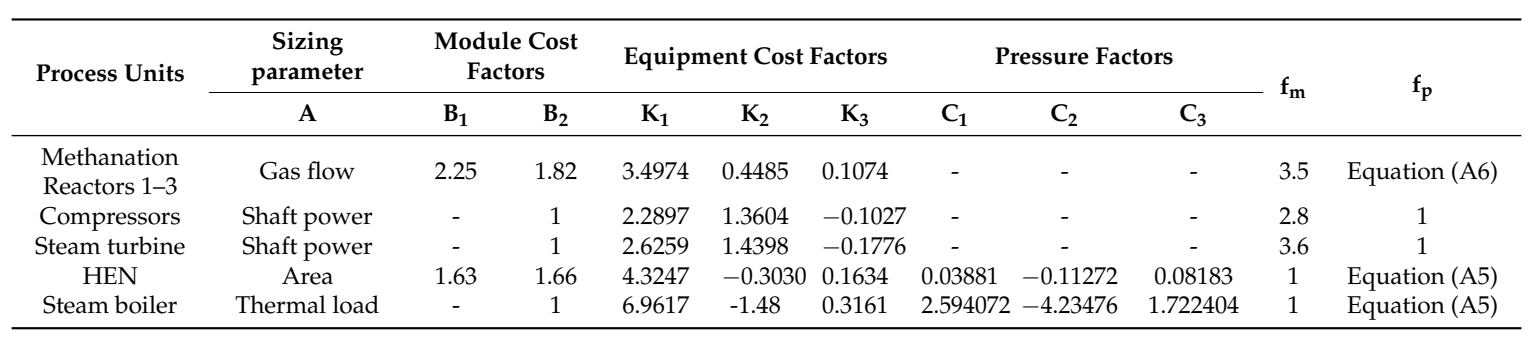

The capital investment is calculated according to Equations (A1)-(A6):

$$
\begin{gathered}
\mathrm{CI}=\left[1.18 \sum_{i=1}^{n} \mathrm{C}_{\mathrm{BM}, i}+0.5 \sum_{i=1}^{n} \mathrm{C}_{\mathrm{BM}, i}^{0}\right]+\sum_{j=1}^{m} \mathrm{f}_{j} \mathrm{C}_{\mathrm{E}, j} \\
\mathrm{C}_{\mathrm{BM}, i}=\mathrm{f}_{\mathrm{BM}, i} \mathrm{C}_{\mathrm{p}, i}^{\mathrm{o}}=\mathrm{C}_{\mathrm{p}, i}^{\mathrm{o}}\left(\mathrm{B}_{1, i}+\mathrm{B}_{2, i} \mathrm{f}_{\mathrm{m}, i} \mathrm{f}_{\mathrm{p}, i}\right) \\
\mathrm{C}_{\mathrm{BM}, i}^{0}=\mathrm{C}_{\mathrm{p}, i}^{\mathrm{o}}\left(\mathrm{B}_{1, i}+\mathrm{B}_{2, i}\right) \\
\log _{10} \mathrm{C}_{\mathrm{p}, i}^{\mathrm{o}}=\mathrm{K}_{1, i}+\mathrm{K}_{2, i} \log _{10}(\mathrm{~A})+\mathrm{K}_{3, i}\left[\log _{10}(\mathrm{~A})\right]^{2} \\
\log _{10} \mathrm{f}_{\mathrm{p}, i}=\mathrm{C}_{1, i}+\mathrm{C}_{2, i} \log _{10}(\mathrm{P})+\mathrm{C}_{3, i}\left[\log _{10}(\mathrm{P})\right]^{2} \\
\mathrm{f}_{\mathrm{p}, i}=\frac{\frac{(\mathrm{P}+1) \mathrm{D}}{2[850-0.6(\mathrm{P}+1)]}+0.00315}{0.0063}
\end{gathered}
$$

\section{Appendix B}

Description of the Streams in the Process Flow Diagram 
Table B1. Stream numbers (as depicted in Figure 1) and description.

\begin{tabular}{|c|c|}
\hline Stream Number & Description \\
\hline 1 & BFM composition as received, i.e., $55 \%$ moisture content \\
\hline 2 & BFM composition prior to gasification, i.e., dried to $10 \%$ moisture content \\
\hline 3 & Air \\
\hline 4 & $\begin{array}{l}\text { Air was converted to oxygen based on the mass balance of oxygen. Compression and actual separation units were omitted, and only the } \\
\text { power consumption and "pass rate" was defined; } 233 \text { g- } \mathrm{O}_{2} / \mathrm{kg} \text {-air }\left(100 \% \mathrm{O}_{2}\right) ; 353 \mathrm{~kJ} \text {-el } / \mathrm{kg} \text {-air }\end{array}$ \\
\hline 5 & Compressed to 15 bar at an isentropic efficiency of $74 \%$ \\
\hline 6 & Preheated to saturated temperature of steam at 15 bar if the gas temperature is lower than that. \\
\hline 7 & Saturated steam at 15 bar \\
\hline 8 & Adiabatic mixing of $\mathrm{O}_{2}$ and steam. The pressure was adjusted to the lower side if there were any pressure difference. \\
\hline 9 & BFM gasification using $\mathrm{O}_{2}$ steam as the oxidizing agent. The detailed calculation method is stated in our previous publication [20]. \\
\hline 10 & Cooled down to $350^{\circ} \mathrm{C}$ to recover heat (it is $350^{\circ} \mathrm{C}$ in order to avoid tar condensation). \\
\hline 11 & Cooled down to room temperature, hence the water was condensed. We assumed that there was a gas cleaning step here, as well. \\
\hline 12 & Compressed to 30 bar at an isentropic efficiency of $74 \%$ \\
\hline 13 & Heated to $398^{\circ} \mathrm{C}$ (according to the data from the ICI process) \\
\hline 14 & Saturated steam at 30 bar \\
\hline 15 & Adiabatic mixing of syngas with steam. The pressure was adjusted to the lower side if there were any pressure difference. \\
\hline 16 & Methanation Reactor $1 ; 10 \%$ of pressure loss and $5 \%$ of heat loss (adiabatic equilibrium reactor) \\
\hline 17 & Heat exchanger (inter-cooling) \\
\hline 18 & Methanation Reactor $2 ; 10 \%$ of pressure loss and $5 \%$ of heat loss (adiabatic equilibrium reactor) \\
\hline 19 & Heat exchanger (inter-cooling) \\
\hline 20 & Methanation Reactor $3 ; 10 \%$ of pressure loss and $5 \%$ of heat loss (adiabatic equilibrium reactor) \\
\hline 21 & Condensing heat exchanger (the vapor pressure of the steam remained as saturated pressure after a certain temperature) \\
\hline 22 & Compressed to 30 bar at an isentropic efficiency of $74 \%$ \\
\hline 23 & Separation of $\mathrm{CO}_{2}\left(98 \%\right.$ of $\mathrm{CO}_{2}$ and $1 \%$ of $\mathrm{CH}_{4}$ removed); electricity consumption of $0.576 \mathrm{MJ} / \mathrm{Nm}^{3}$ of $\mathrm{CO}_{2}$ \\
\hline
\end{tabular}


Table B2. Streams mass flow rates, thermodynamic state and composition.

\begin{tabular}{|c|c|c|c|c|c|c|c|c|c|c|c|c|c|c|c|c|c|c|c|}
\hline \multirow{2}{*}{$\begin{array}{l}\text { Stream } \\
\text { Number }\end{array}$} & \multicolumn{6}{|c|}{$\begin{array}{l}\text { Mass Flow Rate, Thermodynamic State } \\
\text { and Energy Content }\end{array}$} & \multicolumn{6}{|c|}{ Solid Biomass Composition wt \% } & \multicolumn{7}{|c|}{ Gas Composition vol \% } \\
\hline & $\underset{(\mathrm{kg} / \mathrm{s})}{\mathrm{m}}$ & $\begin{array}{c}P \\
\text { (bar) }\end{array}$ & $\mathbf{T}(\mathbf{K})$ & $\begin{array}{c}\mathrm{h} \\
(\mathrm{MJ} / \mathrm{kg})\end{array}$ & $\begin{array}{l}\text { LHV } \\
(\mathrm{MJ} / \mathrm{kg})\end{array}$ & $\begin{array}{c}\mathrm{Q} \\
(\mathrm{MW})\end{array}$ & Moisture & $\mathrm{C}$ & $\mathbf{H}$ & $\mathbf{O}$ & $\mathbf{N}$ & Ash & $\mathrm{O}_{2}$ & $\mathrm{~N}_{2}$ & $\mathbf{H}_{2}$ & $\mathrm{CO}$ & $\mathrm{CO}_{2}$ & $\mathrm{H}_{2} \mathrm{O}$ & $\mathrm{CH}_{4}$ \\
\hline 1 & 14.09 & 1.01 & 275.15 & 0.00 & 7.44 & 104.81 & 55.00 & 22.99 & 2.75 & 18.59 & 0.08 & 0.59 & - & - & - & - & - & - & - \\
\hline 2 & 7.04 & 1.01 & 348.15 & 0.57 & 17.32 & 126.00 & 10.00 & 45.98 & 5.50 & 37.18 & 0.16 & 1.18 & - & - & - & - & - & - & - \\
\hline 3 & 9.94 & 1.01 & 288.15 & 0.00 & 0.00 & 0.00 & - & - & - & - & - & - & 21.00 & 79.00 & 0.00 & 0.00 & 0.00 & 0.00 & 0.00 \\
\hline 4 & 2.42 & 1.01 & 288.15 & 0.00 & 0.00 & 0.00 & - & - & - & - & - & - & 100.00 & 0.00 & 0.00 & 0.00 & 0.00 & 0.00 & 0.00 \\
\hline 5 & 2.42 & 15.00 & 658.70 & 0.36 & 0.00 & 0.87 & - & - & - & - & - & - & 100.00 & 0.00 & 0.00 & 0.00 & 0.00 & 0.00 & 0.00 \\
\hline 6 & 2.42 & 15.00 & 658.70 & 0.36 & 0.00 & 0.87 & - & - & - & - & - & - & 100.00 & 0.00 & 0.00 & 0.00 & 0.00 & 0.00 & 0.00 \\
\hline 7 & 3.52 & 15.00 & 491.45 & 0.39 & 0.00 & 1.37 & - & - & - & - & - & - & 0.00 & 0.00 & 0.00 & 0.00 & 0.00 & 100.00 & 0.00 \\
\hline 8 & 5.95 & 15.00 & 535.00 & 0.38 & 0.00 & 2.24 & - & - & - & - & - & - & 27.93 & 0.00 & 0.00 & 0.00 & 0.00 & 72.07 & 0.00 \\
\hline 9 & 12.91 & 15.00 & 993.00 & 1.23 & 7.64 & 114.47 & - & - & - & - & - & - & 0.00 & 0.06 & 14.92 & 29.16 & 7.79 & 43.34 & 4.73 \\
\hline 10 & 12.91 & 15.00 & 623.00 & 0.55 & 7.64 & 105.72 & - & - & - & - & - & - & 0.00 & 0.06 & 14.92 & 29.16 & 7.79 & 43.34 & 4.73 \\
\hline 11 & 8.01 & 15.00 & 303.15 & 0.02 & 12.32 & 98.83 & - & - & - & - & - & - & 0.00 & 0.11 & 26.26 & 51.32 & 13.71 & 0.28 & 8.32 \\
\hline 12 & 8.01 & 30.00 & 380.03 & 0.13 & 12.32 & 99.69 & - & - & - & - & - & - & 0.00 & 0.11 & 26.26 & 51.32 & 13.71 & 0.28 & 8.32 \\
\hline 13 & 8.01 & 30.00 & 671.15 & 0.56 & 12.32 & 103.18 & - & - & - & - & - & - & 0.00 & 0.11 & 26.26 & 51.32 & 13.71 & 0.28 & 8.32 \\
\hline 14 & 2.80 & 30.00 & 671.15 & 0.75 & 0.00 & 2.10 & - & - & - & - & - & - & 0.00 & 0.00 & 0.00 & 0.00 & 0.00 & 100.00 & 0.00 \\
\hline 15 & 10.81 & 30.00 & 671.15 & 0.61 & 9.13 & 105.29 & - & - & - & - & - & - & 0.00 & 0.08 & 18.30 & 35.78 & 9.55 & 30.49 & 5.80 \\
\hline 16 & 10.81 & 27.00 & 998.15 & 1.18 & 8.07 & 100.02 & - & - & - & - & - & - & 0.00 & 0.09 & 15.22 & 13.68 & 30.84 & 24.74 & 15.43 \\
\hline 17 & 10.81 & 27.00 & 598.15 & 0.46 & 8.07 & 92.32 & - & - & - & - & - & - & 0.00 & 0.09 & 15.22 & 13.68 & 30.84 & 24.74 & 15.43 \\
\hline 18 & 10.81 & 24.30 & 748.05 & 0.69 & 7.42 & 87.70 & - & - & - & - & - & - & 0.00 & 0.11 & 2.83 & 0.69 & 43.02 & 28.22 & 25.14 \\
\hline 19 & 10.81 & 24.30 & 573.15 & 0.40 & 7.42 & 84.60 & - & - & - & - & - & - & 0.00 & 0.11 & 2.83 & 0.69 & 43.02 & 28.22 & 25.14 \\
\hline 20 & 10.81 & 21.87 & 671.15 & 0.55 & 7.39 & 85.86 & - & - & - & - & - & - & 0.00 & 0.11 & 1.26 & 0.15 & 43.50 & 29.05 & 25.94 \\
\hline 21 & 8.85 & 21.87 & 313.15 & 0.03 & 9.02 & 80.13 & - & - & - & - & - & - & 0.00 & 0.15 & 1.78 & 0.21 & 61.09 & 0.34 & 36.44 \\
\hline 22 & 8.85 & 30.00 & 347.67 & 0.07 & 9.02 & 80.48 & - & - & - & - & - & - & 0.00 & 0.15 & 1.78 & 0.21 & 61.09 & 0.34 & 36.44 \\
\hline 23 & 1.75 & 30.00 & 347.67 & 0.13 & 45.11 & 79.33 & - & - & - & - & - & - & 0.00 & 0.38 & 4.47 & 0.52 & 3.07 & 0.85 & 90.71 \\
\hline
\end{tabular}




\section{References}

1. Christiansen, L., Ed.; Swedish Statistical Yearbook of Forestry; Swedish Forest Agency: Jönköping, Sweden, 2014.

2. Anderson, J.-O.; Toffolo, A. Improving energy efficiency of sawmill industrial sites by integration with pellet and CHP plants. Appl. Energy 2013, 111, 791-800. [CrossRef]

3. Duret, A.; Friedli, C.; Maréchal, F. Process design of synthetic natural gas (SNG) production using wood gasification. J. Clean Prod. 2005, 13, 1434-1446. [CrossRef]

4. Arvidsson, M.; Morandin, M.; Harvey, S. Biomass gasification-based syngas production for a conventional oxo synthesis plant-Process modeling, integration opportunities, and thermodynamic performance. Energy Fuels 2014, 28, 4075-4087. [CrossRef]

5. Hamelinck, C.N.; Faaij, A.P. Future prospects for production of methanol and hydrogen from biomass. J. Power Sources 2002, 111, 1-22. [CrossRef]

6. Kopyscinski, J.; Schildhauer, T.J.; Biollaz, S.M.A. Production of synthetic natural gas (SNG) from coal and dry biomass-A technology review from 1950 to 2009. Fuel 2010, 89, 1763-1783. [CrossRef]

7. Pihl, E.; Heyne, S.; Thunman, H.; Johnsson, F. Highly efficient electricity generation from biomass by integration and hybridization with combined cycle gas turbine (CCGT) plants for natural gas. Energy 2010, 35, 4042-4052. [CrossRef]

8. Zwart, R.W.R.; Boerrigter, H.; Deurwaarder, E.P.; van der Meijden, C.M.; van Paasen, S.V.B. Production of Synthetic Natural Gas (SNG) from Biomass: Development and Operation of an Integrated Bio-SNG System; ECN-E-06-018; Energy research center of the Netherlands (ECN): Petten, The Netherlands, 2006; p. 62.

9. Gassner, M.; Baciocchi, R.; Maréchal, F.; Mazzotti, M. Integrated design of a gas separation system for the upgrade of crude SNG with membranes. Chem. Eng. Process. Process. Intensif. 2009, 48, 1391-1404. [CrossRef]

10. Van der Meijden, C.M.; Veringa, H.J.; Rabou, L.P.L.M. The production of synthetic natural gas (SNG): A comparison of three wood gasification systems for energy balance and overall efficiency. Biomass Bioenergy 2010, 34, 302-311. [CrossRef]

11. Juraščík, M.; Sues, A.; Ptasinski, K.J. Exergy analysis of synthetic natural gas production method from biomass. Energy 2010, 35, 880-888. [CrossRef]

12. Gassner, M.; Maréchal, F. Thermo-economic process model for thermochemical production of synthetic natural gas (SNG) from lignocellulosic biomass. Biomass Bioenergy 2009, 33, 1587-1604. [CrossRef]

13. Zhang, W.; He, J.; Engstrand, P.; Björkqvist, O. Economic evaluation on bio-synthetic natural gas production integrated in a thermomechanical pulp mill. Energies 2015, 8, 12795-12809. [CrossRef]

14. Davis, W.; Martin, M. Optimal year-round operation for methane production from $\mathrm{CO}_{2}$ and water using wind and/or solar energy. J. Clean Prod. 2014, 80, 252-261. [CrossRef]

15. Davis, W.; Martin, M. Optimal year-round operation for methane production from $\mathrm{CO}_{2}$ and water using wind energy. Energy 2014, 69, 497-505. [CrossRef]

16. Giglio, E.; Lanzini, A.; Santarelli, M.; Leone, P. Synthetic natural gas via integrated high-temperature electrolysis and methanation: Part II-Economic analysis. J. Energy Storage 2015, 2, 64-79. [CrossRef]

17. Giglio, E.; Lanzini, A.; Santarelli, M.; Leone, P. Synthetic natural gas via integrated high-temperature electrolysis and methanation: Part I-energy performance. J. Energy Storage 2015, 1, 22-37. [CrossRef]

18. Gómez-Barea, A.; Leckner, B. Modeling of biomass gasification in fluidized bed. Prog. Energy Combust. Sci. 2010, 36, 444-509. [CrossRef]

19. Shiflett, M.B.; Drew, D.W.; Cantini, R.A.; Yokozeki, A. Carbon dioxide capture using ionic liquid 1-butyl-3-methylimidazolium acetate. Energy Fuels 2010, 24, 5781-5789. [CrossRef]

20. Tanaka, Y.; Mesfun, S.; Umeki, K.; Toffolo, A.; Tamaura, Y.; Yoshikawa, K. Thermodynamic performance of a hybrid power generation system using biomass gasification and concentrated solar thermal processes. Appl. Energy 2014, 160, 664-672. [CrossRef]

21. Lazzaretto, A.; Toffolo, A. A method to separate the problem of heat transfer interactions in the synthesis of thermal systems. Energy 2008, 33, 163-170. [CrossRef]

22. Mesfun, S.; Toffolo, A. Optimization of process integration in a Kraft pulp and paper mill—Evaporation train and CHP system. Appl. Energy 2013, 107, 98-110. [CrossRef]

23. Kemp, C.-I. Pinch Analysis and Process Integration: A User Guide on Process Integration for the Efficient Use of Energy, 2nd ed.; Butterworth-Heinemann Ltd.: Oxford, UK, 2007. 
24. Turton, R.; Bailie, R.C.; Whiting, W.B.; Shaeiwitz, J.A. Analysis, Synthesis, and Design of Chemical Processes, 2nd ed.; Printice Hall PTR: Upper Saddle River, NJ, USA, 2003.

25. Heyne, S.; Harvey, S. Assessment of the energy and economic performance of second generation biofuel production processes using energy market scenarios. Appl. Energy 2013, 101, 203-212. [CrossRef]

26. Mesfun, S.; Toffolo, A. Integrating the processes of a Kraft pulp and paper mill and its supply chain. Energy Convers. Manag. 2015, 103, 300-310. [CrossRef]

27. Wetterlund, E.; Söderström, M. Biomass gasification in district heating systems-The effect of economic energy policies. Appl. Energy 2010, 87, 2914-2922. [CrossRef]

28. Börjesson, M.; Ahlgren, E.O. Biomass gasification in cost-optimized district heating systems-A regional modelling analysis. Energy Policy 2010, 38, 168-180. [CrossRef]

29. Heyne, S.; Harvey, S. Impact of choice of $\mathrm{CO}_{2}$ separation technology on thermo-economic performance of bio-SNG production processes. Int. J. Energy Res. 2014, 38, 299-318. [CrossRef]

30. Hamelinck, C.; Faaij, A.; Denuil, H.; Boerrigter, H. Production of FT transportation fuels from biomass; technical options, process analysis and optimisation, and development potential. Energy 2004, 29, 1743-1771. [CrossRef]

31. Li, H.; Chen, Q.; Zhang, X.; Finney, K.N.; Sharifi, V.N.; Swithenbank, J. Evaluation of a biomass drying process using waste heat from process industries: A case study. Appl. Therm. Eng. 2012, 35, 71-80. [CrossRef]

32. Seemann, M.C.; Schildhauer, T.J.; Biollaz, S.M.A. Fluidized bed methanation of wood-derived producer gas for the production of synthetic natural gas. Ind. Eng. Chem. Res. 2010, 49, 7034-7038. [CrossRef]

33. Lazzaretto, A.; Macor, A. Direct calculation of average and marginal costs from the productive structure of an energy system. J. Energy Resour. Technol. 1995, 117, 171. [CrossRef]

34. Worley, M.; Yale, J. Biomass Gasification Technology Assessment Consolidated Report; Contract No. DE-AC36-08GO28308; NREL: Golden, CO, USA, 2012.

(C) 2016 by the authors; licensee MDPI, Basel, Switzerland. This article is an open access article distributed under the terms and conditions of the Creative Commons Attribution (CC-BY) license (http://creativecommons.org/licenses/by/4.0/). 